Available online at: http://ejournal-balitbang.kkp.go.id/index.php/iaj

\title{
THE APPLICATION OF LIFE CYCLE ASSESSMENT TO EVALUATE WATER QUALITY CONDITION AROUND FISH CAGES IN CIRATA RESERVOIR, INDONESIA
}

\author{
Tri Heru Prihadi\#, Adang Saputra, Imam Taufik, and Idil Ardi \\ Institute for Freshwater Aquaculture Researh and Fisheries Extension
}

(Received 11 August 2017; Final revised 6 September 2017; Accepted 6 September 2017)

\begin{abstract}
Life Cycle Assessment (LCA) is an analytical tool used primarily for evaluating environmental conditions. The sources of decomposed organic matters in Cirata Reservoir originate from industrial activities, household waste, agricultural waste, and effluent from floating fish net cages. The wastes consist mainly of fat, protein, and carbohydrate. Bacteria are responsible for aerobic decomposition process of organic matters in the sediment. As bacteria consume oxygen during the decomposition processes, significant depletion of dissolved oxygen level in the waters may occur. This happens in Cirata Reservoir where a low level of oxygen in the water leads to anaerobic decomposition processes at the bottom of the reservoir. The porpuse of this study was to evaluate Cirata Reservoir water conditions, in terms of water quality, organic sediment and organic materials level based on the application of LCA. In this study, water and sediment samples were collected. Water quality conditions were measured in-situ. Water and sediment samples were analyzed in the laboratories. The results of the analyses showed that water quality condition in all sampling stations was relatively homogeneous. Based on the level of decomposition of organic matter, water quality conditions in Cirata reservoir could be classified as Class I, II, and III in IKA_STORET scale and categorized as poor. DO, sulfide, phenol, BOD, COD, total phosphate were outside the ranges of acceptable water quality standards.
\end{abstract}

\section{KEYWORDS: Cirata Reservoir; anaerobic; sediment decomposition; organic matter}

\section{INTRODUCTION}

The application of a quantitative model such as life cycle assessment (LCA) has received positive responses in the implementation of sustainable aquaculture. LCA, also known as life-cycle analysis, ecobalance, and cradle-to-grave analysis is a quantitative technique to assess environmental impacts associated with all the stages of a product's life. Designers used this process to improve their products. LCAs can also be used in avoiding a narrow outlook on environmental concerns by evaluating the potential impacts associated with identified aquaculture inputs and releases and interpreting the results for stakeholders to make a better-informed decision (Prihadi et al., 2008).

Cirata Reservoir is located in West Bandung, West Java Province and covers an area of 6200 ha. This reservoir is important for West Java Province. At least,

\footnotetext{
* Correspondence: Institute for Freshwater Aquaculture Research and Fisheries Extension. Jl. Sempur No.1, Bogor 16154, West Java, Indonesian.

Phone: + 622518313200

E-mail: triheru_p@yahoo.com
}

$30 \%$ of freshwater fish produced by fish farmers in West Jawa Province comes from 39.690 floating net cages operating on this water body. However, the overcrowding of floating net cages in Cirata has contributed a significant impact to the reservoir's aquatic environment specifically from the uneaten fish feed. Simarmata (2007) stated that the enrichment of organic materials in the sediment stimulated oxygenbased microbial activities causing de-oxygenation of the substrate and water column. If the supply of oxygen in the hypolimnion was not sufficient for bacteria to decompose organic materials, a critical stage will occur which signals a turning point of decomposition process from aerobic to anaerobic.

Besides oxygen deficiency in the hypolimnion, the cause of mass mortality of fish cultured in Cirata Reservoir is the toxic gases escaped and rising from the seabed to the surface, especially during the rainy season. The availability of toxic gases at the bottom of the water depends on the speed of bacterial decomposition. Therefore, it is necessary to study the level of organic materials in the sediment of Cirata Reservoir to understand the dynamics of nutrient recycling within the water body. The purpose of the 
recent research was to evaluate Cirata Reservoir water conditions, in terms of water quality, organic sediment and organic materials level based on the application of LCA.

\section{MATERIALS AND METHODS}

The research was done in 2007 at Cirata Reservoir located between $66^{\circ} 40^{\prime}$ to $6^{\circ} 48^{\prime} S$ and $107^{\circ} 14^{\prime}$ to $107^{\circ} 22^{\prime} E$. This research was carried out in two stages, laboratory and field activities. The field activity was done through surveys. Simple random sampling was used to determine the sampling locations (Clark \& Hosking, 1986). Sample collection was done at the reservoir's inlet zone (station 1), mid zone (station 2), and outlet zone (station 3) (Figure 1).

Tools used for sampling were GPS, Secchi disk, Polyurethane bottle, BOD bottle, DO meter, titrimetry tools, cool box, pH meter, Petersen-grab, and plankton net. Laboratory analyses used equipment such as vacuum pump, refrigerator, spectrophotometer, anaIytic scale, hot plate, oven, distillation apparatus, and distillation glass. Chemical compounds $\left(\mathrm{H}_{2} \mathrm{SO}_{4^{\prime}} \mathrm{HNO}_{3^{\prime}}\right.$ $\mathrm{HgCl}$, and Lugol) were used as sample preservatives.

Water samples were collected in the three stations and the laboratory activities used 9 tanks measuring $30 \mathrm{~cm} \times 40 \mathrm{~cm} \times 60 \mathrm{~cm}$ in size. Each tank was filled with sediment from different stations of Cirata reservoir up to $10 \mathrm{~cm}$ of thickness. Water was added to each tank approximately $40 \mathrm{~cm}$ high. The tanks were wrapped in black plastic sheets. The water conditions were observed at $0,20,40$ and 60 days. Water parameters measured were temperature (thermometer), DO (DO meter), $\mathrm{pH}$ (pH meter), carbon dioxide (APHA, 1989), sulphide (APHA, 1989), nitrite (SNI 06-6989.9-2005), nitrate (SNI 06-6989.30-2005), phenol (APHA, 1989), biochemical oxygen demand (BOD) (APHA, 1989), chemical oxygen demand (COD) (titration), total phosphate (APHA, 1989), orthophosphate (APHA, 1989), alkalinity (titration) and calcium (EDTA murexide). Sediment parameters measured were temperature (thermometer), DO (DO meter), $\mathrm{pH}$ (pH meter), pH, calcium (EDTA murexide), potential redox and C-organic (titration). Total sulfur reducing bacterial count was carried out at the beginning and the end of the research ( 0 and 60 days).

The obtained data were evaluated using STORET method (Canter, 1977: Minister for the Environment Decree NO. 115, 2003), and the result was presented in figures and tables then descriptively discussed.

\section{RESULTS AND DISCUSSION}

Water quality evaluation in each station was based on the government regulation No. 82/2001 regard-

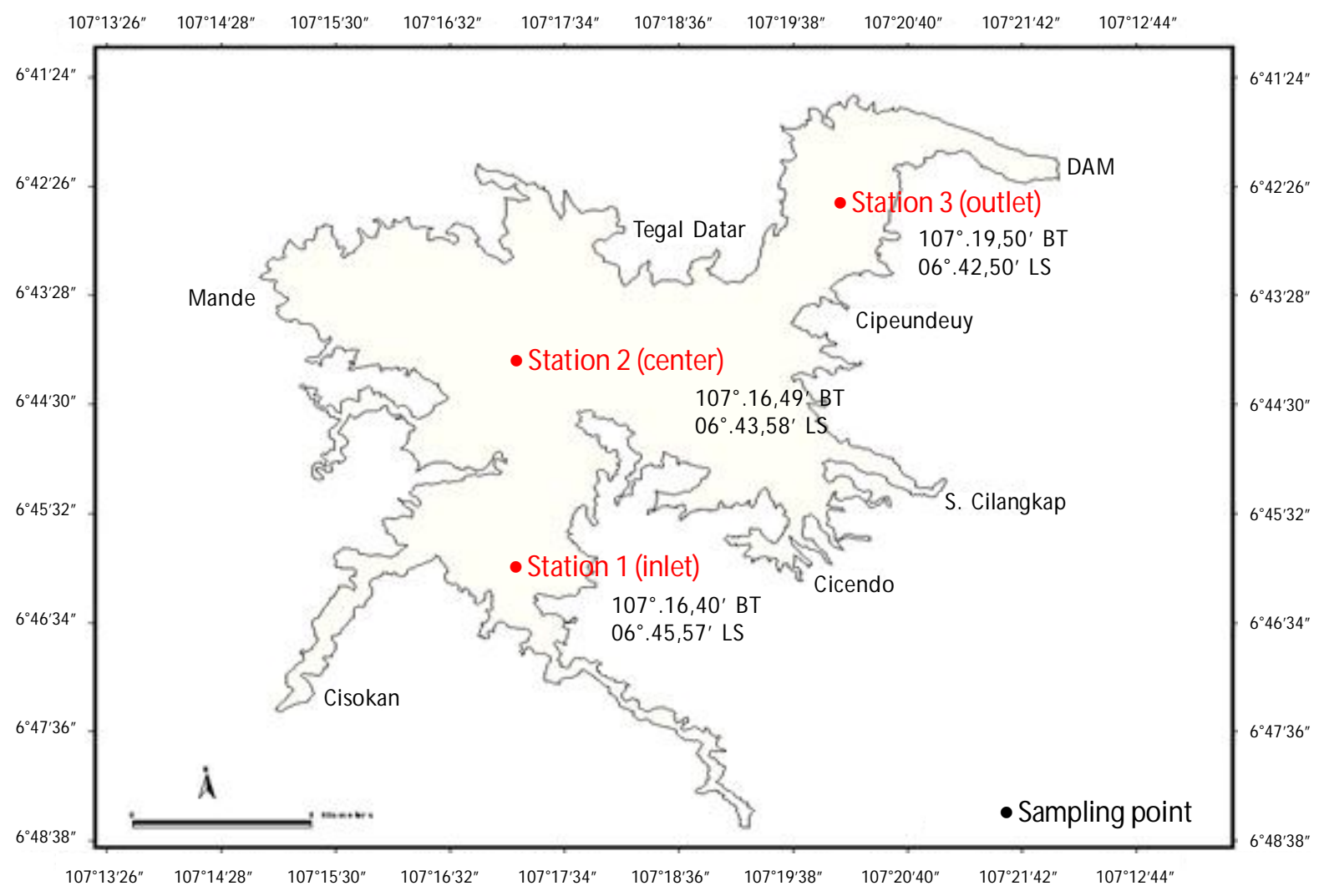

Figure 1. Locations of sampling stations in Cirata Reservoir. 
ing Water Quality Standard conducted using IKA_STORET Method. IKA_STORET scores showed that water quality condition for in Cirata reservoir water was classified as Class I, II, III which indicated heavy polluted water, while Class IV was moderately polluted (Table 1).

The pollution of Cirata reservoir was mainly sourced from the rapid development of floating cages for fish farming. Prihadi (2005) reported that in 1999 there were 27.786 floating cages in Cirata reservoir. The number had increased 11,904 units to 39.690 floating cages in 2007 (DKP, 2007). This led to the deteriorating condition of the reservoir. According to Prihadi (2005), the mismanagement of feeding activity had caused excessive accumulation of organic matter at the bottom of the reservoir. The decomposition of the organic material has consumed a most of DO on and within the seabed leading to an oxygen-deprived environment. The low level of DO in the water has changed the decomposition process to anaerobic which produced toxic gases such as ammonia, hydrogen sulfide and nitrite which polluted the entire water column and endangered all living organism in the reservoir when an upwelling event occurs.

The results of water and sediment measurement (temperature, pH, DO and redox potential) are presented in Table 2. The levels of carbon dioxide, $\mathrm{H}_{2} \mathrm{~S}$, Ammonia, Nitrite, Nitrate, phenol, BOD, COD, total phosphate, orthophosphate, alkalinity, hardness, calcium during the research are presented in Table 3.

The presence of organic materials was measured using two variables, BOD and COD. The measurement of BOD assumed that the oxygen consumed by microorganism during the decomposition process of organic materials. The measurement results are presented in Table 3.

The overall value of BOD was relatively high, especially during day 20 . This was caused by the escalation of organism activity in breaking down organic materials (Table 3 ). Therefore, it can be construed that the higher the BOD, the higher the activity of the organism to break down organic compounds in the waters. Furthermore, Effendi et al. (2006) reported that the decomposition of organic materials basically takes place in two phases. In the first phase, the organic materials broke down into inorganics materials. In the second phase, the unstable inorganics materials were oxidized into more stable inorganics materials such as ammonia which was oxidized into nitrites and nitrate (nitrification) (Figure 2A and B).

The measurement of ammonia level showed the highest level of ammonia occurred in day 20 at station 2, followed by station 3 and 1 successively. The highest estimation level of nitrite also happened on day 20 at station 3, 2 and 1 successively. The highest level of nitrite occurred in day 40 in station 3,2 and 1 successively (Table 3). The high level of ammonia, nitrite, and nitrate was presumably caused by the low concentration of oxygen while the $\mathrm{pH}$ and temperature were high.

The high level of ammonia in station 2 (Figure 3) was caused by the feed excess and fecal dirt excreted by fish reared in a high density of floating cages in the area. The high level of nitrite and nitrate in station 3 was allegedly caused by the accumulation of excess feed which was not washed away by the current. Topographically, station 3 was situated at the outlet area which was smaller in size than that of station 2 (midsection of the reservoir). Widigdo \& Soewardi (1999) stated that ammonia in the waters was used by phytoplankton in the photosynthesis process.

Furthermore, Metcalf \& Eddy (1991) emphasized that ammonia compound in anaerobic condition was oxidized to nitrite by atrophic bacteria through the microbiological process. The nitrate reduction (denitrification) was done by bacterial activity in anaerobic condition (Effendi et al., 2006). High concentration of ammonia influences the permeability of fish tissue towards water causing lower ionic concentration in their bodies. As a result, oxygen demand will increase within the fish tissue and subsequently dam-

Tabel 1. Water parameters at Cirata Reservoir according to IKA_STORET

\begin{tabular}{|c|c|c|c|c|}
\hline \multirow{2}{*}{$\begin{array}{l}\text { Sampling } \\
\text { station }\end{array}$} & Class 1 & Class II & Class III & Class IV \\
\hline & Unmet parameters & Unmet parameters & Unmet parameters & Unmet parameters \\
\hline \multirow{2}{*}{$\begin{array}{l}\text { Cirata reservoir } \\
\text { (stations I, II, and III) }\end{array}$} & $\begin{array}{l}\text { DO, sulfide, phenol, BOD, } \\
\text { COD, total phosphate }\end{array}$ & $\begin{array}{l}\text { Do, sulfide, phenol, } \\
\text { total phosphate }\end{array}$ & $\begin{array}{l}\text { DO, sulfide, phenol, } \\
\text { total phosphate }\end{array}$ & DO, sulfide, phenol \\
\hline & -52 (TB) & -40 (TB) & -34 (TB) & -30 (TS) \\
\hline
\end{tabular}


Table 2. Minimum and maximum values of measured parameters of water and sediment during the research period

\begin{tabular}{|c|c|c|c|c|c|c|c|c|c|}
\hline \multirow{2}{*}{ Parameter } & \multicolumn{3}{|c|}{ Station I } & \multicolumn{3}{|c|}{ Station II } & \multicolumn{3}{|c|}{ Station III } \\
\hline & Min & Max & Avarage & Min & Max & Avarage & Min & Max & Avarage \\
\hline Waterdissolved oxygen (DO) (mg/L) & 0.4 & 1 & 0.73 & 0.4 & 0.9 & 0.57 & 0.4 & 0.8 & 0.6 \\
\hline Water temperature $\left({ }^{\circ} \mathrm{C}\right)$ & 26 & 28 & 28.1 & 26 & 28 & 28.1 & 26 & 28 & 28.1 \\
\hline Water $\mathrm{pH}$ & 6.5 & 7.5 & 7.12 & 6.3 & 7.4 & 7.33 & 6.2 & 7.4 & 7.28 \\
\hline Sediment dissolved oxygen (DO) (mg/L) & 0 & 0.5 & 0.33 & 0 & 0.3 & 0.3 & 0.4 & 0.8 & 0.6 \\
\hline Sediment temperature $\left({ }^{\circ} \mathrm{C}\right)$ & 26 & 28 & 27.9 & 26 & 28 & 27.9 & 26 & 28 & 27.9 \\
\hline Sediment $\mathrm{pH}$ & 5.1 & 7.1 & 7.06 & 6.2 & 7.1 & 7.1 & 6.3 & 7.2 & 7.07 \\
\hline Potential redox (mV) & -2 & -59 & -48 & -1 & -57 & -50 & -1 & -48 & -40 \\
\hline
\end{tabular}

Table 3. Water and sediment chemical value on day $0,20,40$ and 60 during the research period

\begin{tabular}{|c|c|c|c|c|c|c|c|c|c|c|c|c|}
\hline \multirow{2}{*}{ Parameters } & \multicolumn{4}{|c|}{ Station I } & \multicolumn{4}{|c|}{ Station II } & \multicolumn{4}{|c|}{ Station III } \\
\hline & 0 & 20 & 40 & 60 & 0 & 20 & 40 & 60 & 0 & 20 & 40 & 60 \\
\hline \multicolumn{13}{|l|}{ Water } \\
\hline Carbon dioxide $\left(\mathrm{CO}_{2}\right)(\mathrm{mg} / \mathrm{L})$ & 8.91 & 25.74 & 39.6 & 29.7 & 11.88 & 51.48 & 33.66 & 23.76 & 16.83 & 73.26 & 19.8 & 35.64 \\
\hline Sulphide (mg/L) & $<0.02$ & $<0.02$ & $<0.02$ & $<0.02$ & $<0.02$ & $<0.02$ & $<0.02$ & $<0.02$ & $<0.02$ & $<0.02$ & $<0.02$ & $<0.02$ \\
\hline Ammonia $\left(\mathrm{NH}_{3}{ }^{+}-\mathrm{N}\right)(\mathrm{mg} / \mathrm{L})$ & 0.065 & 3.191 & 2.828 & 1.549 & 0.052 & 3.787 & 3.25 & 1.429 & 0.104 & 3.562 & 3.336 & 1.459 \\
\hline Nitrite $\left(\mathrm{NO}_{2}^{-}-\mathrm{N}\right)(\mathrm{mg} / \mathrm{L})$ & 0.037 & 2.357 & 0.31 & 0.23 & 0.025 & 2.714 & 0.324 & 0.379 & 0.027 & 10.29 & 0.295 & 0.168 \\
\hline Nitrate $\left(\mathrm{NO}_{3}-\mathrm{N}\right)(\mathrm{mg} / \mathrm{L})$ & 0.388 & 1.364 & 2.064 & 1.388 & 0.215 & 1.545 & 2.418 & 1.715 & 0.056 & 2.091 & 2.773 & 2.211 \\
\hline Phenol (mg/L) & $<0.05$ & $<0.05$ & $<0.05$ & $<0.05$ & $<0.05$ & $<0.05$ & $<0.05$ & $<0.05$ & $<0.05$ & $<0.05$ & $<0.05$ & $<0.05$ \\
\hline BOD (mg/L) & 2.24 & 5.76 & 1.79 & 1.64 & 1.25 & 5.66 & 2.69 & 1.33 & 1.39 & 5.92 & 2.71 & 1.35 \\
\hline COD (mg/L) & 12.9 & 11.2 & 6 & 6 & 15.9 & 19.7 & 4.1 & 4 & 13.9 & 8.8 & 6.4 & 6 \\
\hline Total Phosphate (mg/L) & 1.357 & 0.654 & 0.78 & 0.791 & 1.076 & 1.721 & 0.788 & 0.798 & 1.5 & 2.713 & 0.876 & 0.823 \\
\hline Orto phosphate $\left(\mathrm{PO}_{4}{ }^{3-}-\mathrm{P}\right)(\mathrm{mg} / \mathrm{L})$ & 0.373 & 0.503 & 0.628 & 0.621 & 0.19 & 1.11 & 0.602 & 0.556 & 1.291 & 2.547 & 0.628 & 0.71 \\
\hline Alkalinity & 71.64 & 170.9 & 213.6 & 217.5 & 55.72 & 110.5 & 155.3 & 158.6 & 91.54 & 61.74 & 128.4 & 76.84 \\
\hline Hardness & 39.04 & 142.1 & 203 & 169.2 & 60.06 & 132.9 & 147.6 & 150 & 42.04 & 74.24 & 122 & 73.39 \\
\hline Calcium (Ca) (mg/L) & 8.15 & 26.35 & 24.12 & 24.32 & 8.72 & 20.22 & 18.56 & 19.26 & 8 & 12.55 & 11.45 & 12.56 \\
\hline \multicolumn{13}{|l|}{ Sediment } \\
\hline Calcium (Ca) (mg/Kg) & 4.4 & 5.67 & 7.34 & 8.14 & 1.4 & 3.21 & 4.98 & 5.12 & 1.65 & 2.76 & 3.98 & 4.23 \\
\hline C-Organic (\%) & 5.9 & 1.29 & 2.05 & 1.99 & 3.6 & 1.59 & 2.57 & 1.9 & 5.8 & 2.35 & 2.91 & 1.95 \\
\hline
\end{tabular}

ages the gills due to the diminishing capability of blood in carrying oxygen. Ionized ammonia was easily absorbed by the body of an aquatic organism compared to ammonium. Ammonia was more toxic when the level of DO drops (Boyd, 1992). This closely relates to the fact that the higher decomposition of organic materials by a microorganism, the higher the need for oxygen. This will increase the possibility of nitrite forming at the bottom of the waters.

Oxygen levels in the sediment observed during the research in station 1 were between 0.01-0.48 $\mathrm{mg} / \mathrm{L}$ with the average value of $0.33 \mathrm{mg} / \mathrm{L}$, Station 2 were between $0.01-0.30 \mathrm{mg} / \mathrm{L}$ with the average value
$0.30 \mathrm{mg} / \mathrm{L}$ and station 3 varied between $0.40-0.80$ with the average value $0.60 \mathrm{mg} / \mathrm{L}$ (Table 2). The levels of $D O$ in the water observed in station 1 were between $0.40-0.98 \mathrm{mg} / \mathrm{L}$ with the average value of $0.73 \mathrm{mg} / \mathrm{L}$, station 2 ranged between $0.40-0.90 \mathrm{mg} / \mathrm{L}$ with the average value of $0.57 \mathrm{mg} / \mathrm{L}$ and station 3 were between $0.40-0.80$ with average value of 0.60 $\mathrm{mg} / \mathrm{L}$ (Figure $4 \mathrm{~A}$ and $\mathrm{B}$ ). According to the dynamic pattern of DO shown in Figure 4A and 4B, it is clear that the level of DO had decreased due to the decomposition occurred. DO level continued to drop until day 20 which showed anaerobic condition. This was due to the used of oxygen for decomposition 

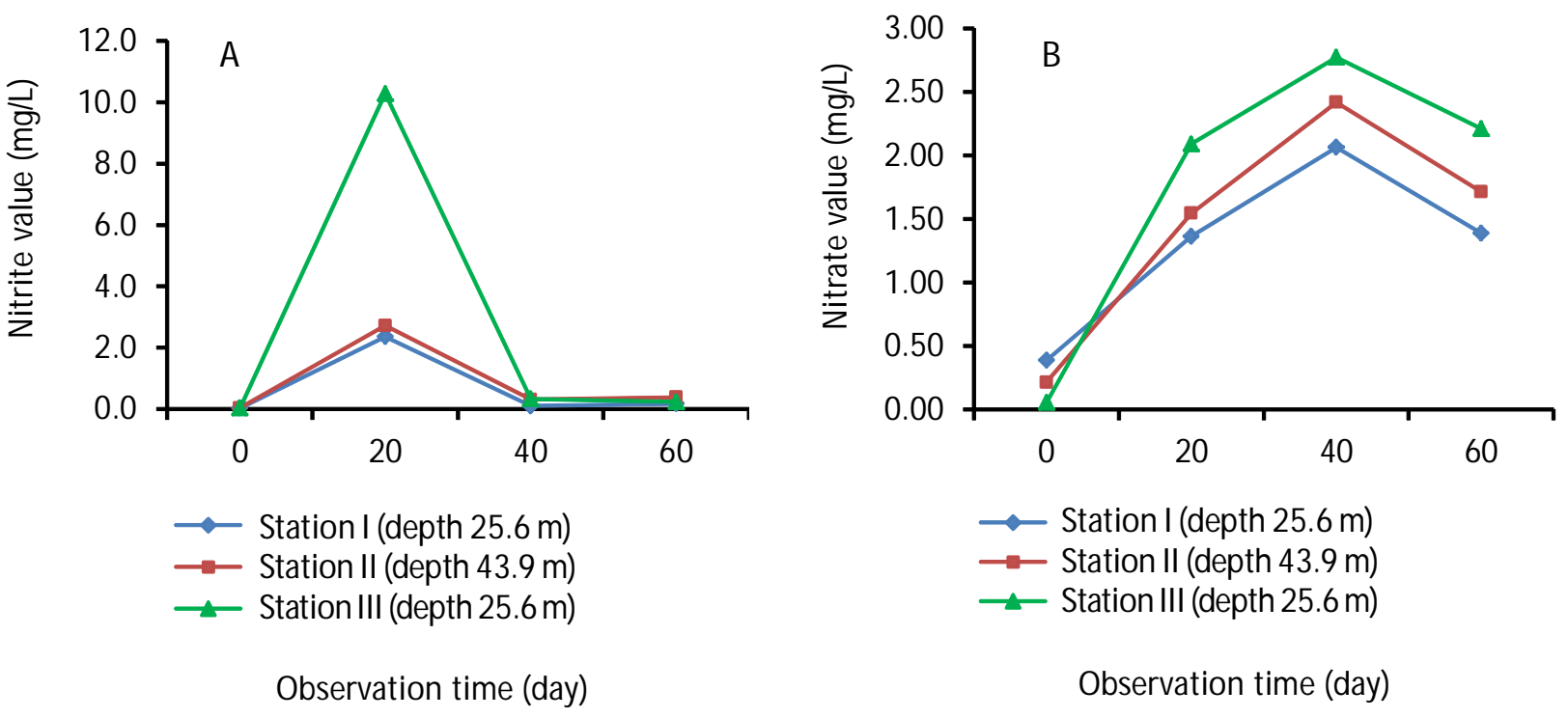

Figure 2. A. Nitrite value estimation ( $\mathrm{mg} / \mathrm{L}$ ) and B. Nitrate value estimation ( $\mathrm{mg} / \mathrm{L}$ ) on day $0,20,40$ and 60 during the research in Cirata.

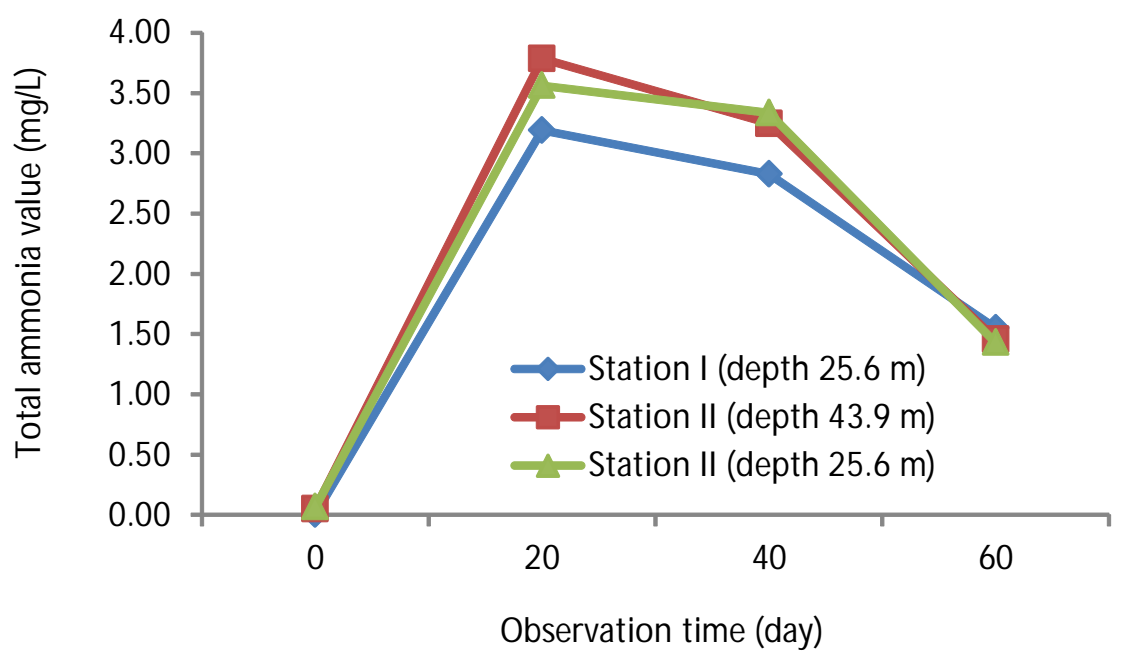

Figure 3. Estimation of ammonia value $(\mathrm{mg} / \mathrm{L})$ on day $0,20,40$ and 60 during the research in Cirata.

process through metabolism of aquatic microorganisms. According to Simarmata (2007), the absence of oxygen did not mean the process of decomposition halted. It remained to happen by using other oxidants such as sulfate and nitrate. The use of sulfate and nitrate in an anaerobic decomposition produced gases such as $\mathrm{H}_{2} \mathrm{~S}$ and ammonia which are toxic to aquatic organisms. The more organic compound, the higher concentration of $\mathrm{H}_{2} \mathrm{~S}$ in the water due to the anaerobic decomposition process.

Potential redox values of sediment media during the research in station 1 were between -2 to $-59 \mathrm{mV}$, with the average value of $-48 \mathrm{mV}$, station 2 were between -1 to $-57 \mathrm{mV}$, with the average value of -50 $\mathrm{mV}$, and station 3 were between -1 to $-48 \mathrm{mV}$, with the average value $-40 \mathrm{mV}$ (Table 2). The dynamic pattern of potential redox in the sediment during the research is presented in Figure 5.

During the research, starting from day 0 to day 60 , the potential redox continued to decrease. This reduction signaled a chemical reaction was occurring in the sediment due to the anaerobic condition. Tebut (1992) reported that a reaction in anaerobic condition had an Oxidation-Reduction Potential (ORP) value of $<50 \mathrm{mV}$. Furthermore, Boyd (1988) reported, in anaerobe mud at the bottom of waters, the value of ORP 


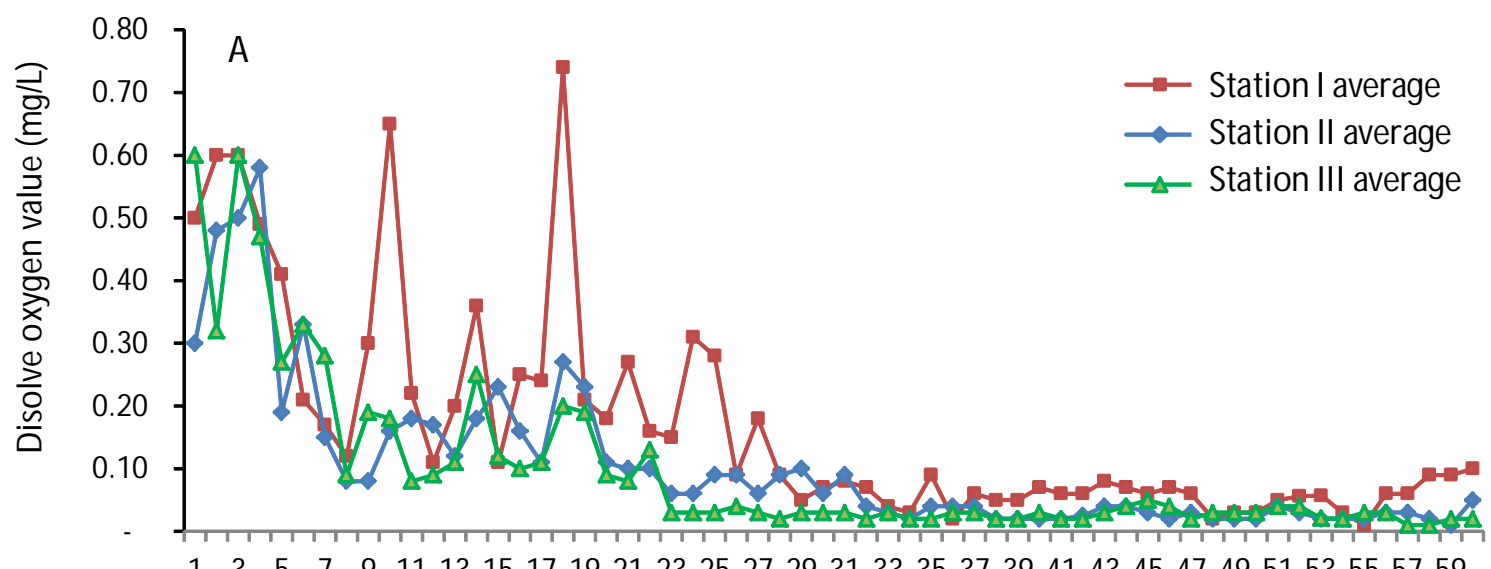

$1 \quad 3 \quad 5 \quad 7 \quad 911131517192123252729313335373941434547495153555759$

Observation time (day)

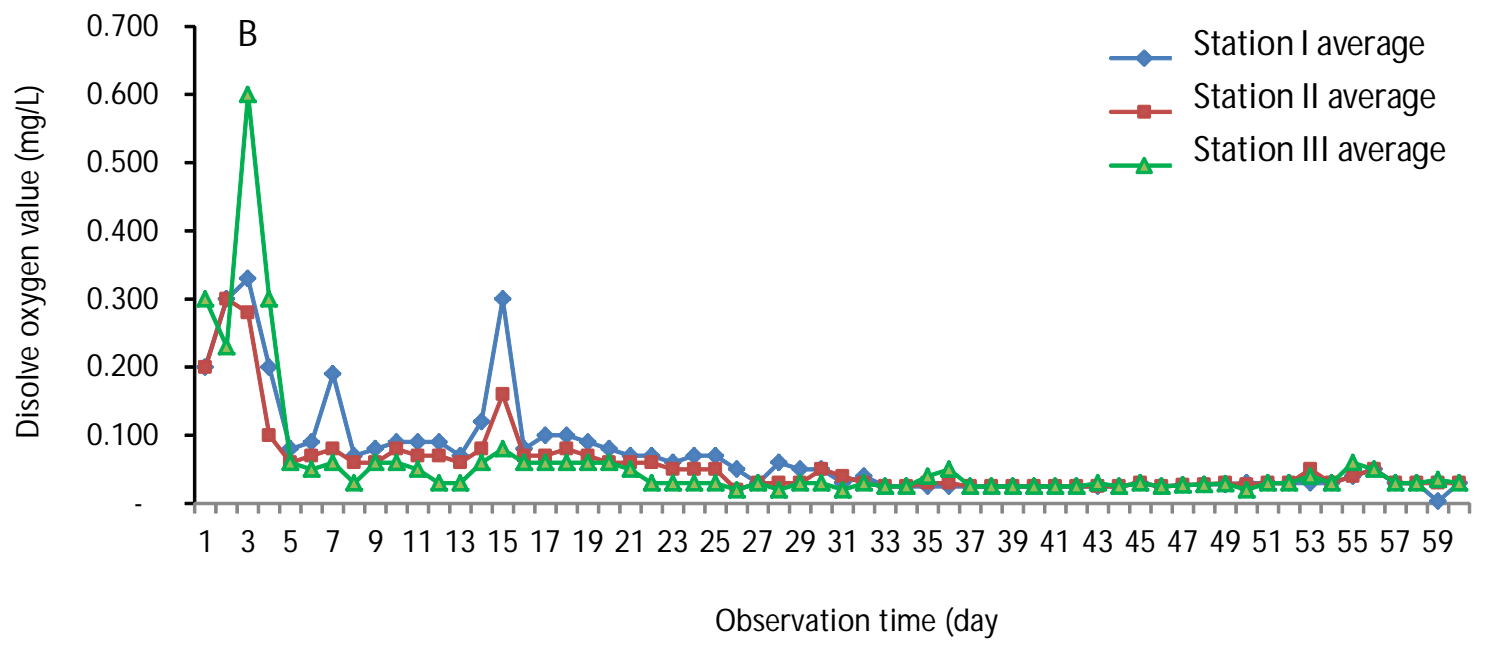

Figure 4. The dynamic of dissolved oxygen ( $\mathrm{mg} / \mathrm{L})$ in sediment $(\mathrm{A})$ and water $(\mathrm{B})$ medium during the research in Cirata.

reached -0.1 Volt. According to Suwoyo (2009), the decomposition process of organic materials occurred both in a reductive condition and oxidative condition. Furthermore, Emiyati (2004) and Suwoyo (2009) pointed out that the level of DO in sediment had considerable influence to the potential value of redox and sediment $\mathrm{pH}$, in addition to being able to be used as a chemical reaction control of water ions in the sediment. The abundance of organic materials, the number of bacteria living in the substrate and the lack of water circulation had led to the lower concentration of oxygen in the substrate. This condition could change substrate condition to a reductive environment.

A significant increase in carbon dioxide was observed in day 20 particularly in station 3 (Table 3). It was suspected that such high concentration was caused by decomposition activity of microorganism during day 20. It is argued that water masses passing through the organic soil in station 2 in which decomposition process was occurring and producing carbon dioxide as a byproduct. Carbon dioxide resulted from this decomposition dissolve in the water masses. Anaerobic decomposition of carbohydrate at the bottom of the waters produced carbon dioxide as the final product. Jeffries \& Mills (1996) emphasized that during the decomposition process, microorganism releases carbon dioxide into the waters. Carbon dioxide is easily dissolved into the water because this gas has high dissolvability. The concentration of $\mathrm{CO}_{2}$ in the waters was determined by respiration activity of the aquatic organisms. If the concentration of $\mathrm{O}_{2}$ in the waters rises, the $\mathrm{CO}_{2}$ level drops. The measured $\mathrm{CO}_{2}$ concentration was slightly higher than $10 \mathrm{mg} / \mathrm{L}$. However, the concentration is still sufficiently toxic to fish because $\mathrm{CO}_{2}$ blocks oxygen binding process by hemoglobin (Zonneveld et al., 1991).

Sulphide concentration during the research in station 1,2, and 3 (on day $0,20,40$ and 60 ) showed similar variations with estimated values below $<0.02$ 
$1 \quad 3 \quad 5 \quad 7 \quad 911131517192123252729313335373941434547495153555759$

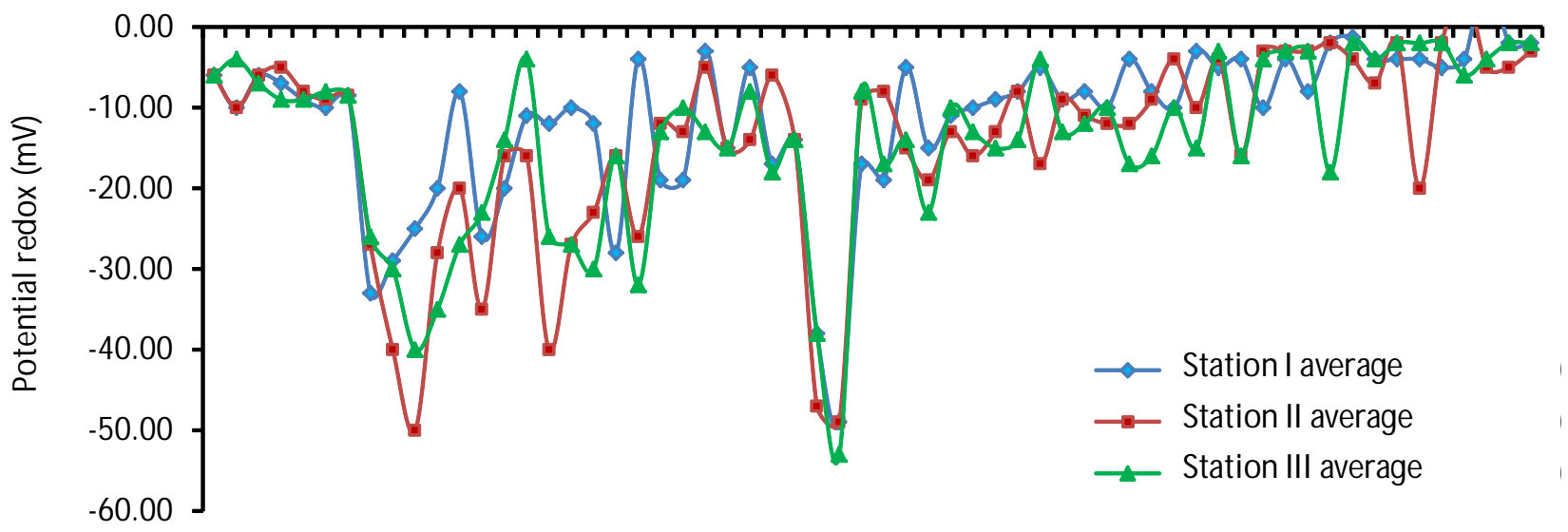

Observation time (day)

Figure 5. The pattern of dynamic potential redox $(\mathrm{mV})$ in the sediment medium during the research.

$\mathrm{mg} / \mathrm{L}$ and produced a rancid smell (Table 3). The high concentration of $\mathrm{H}_{2} \mathrm{~S}$ presumably resulted from degraded organic materials. The rancid smell was caused by the reduction of oxygen and the increase of hydrogen and anion sulfate transformed into hydrogen sulfide in anaerobic condition by heterotroph bacteria during the decomposition of organic materials (Effendi, 2007). Hochheirmer (2000) stated that decomposition of organic materials in an anaerobic condition resulted in gasses such as $\mathrm{CO}_{2}, \mathrm{CH}_{3}$ and $\mathrm{H}_{2} \mathrm{~S}$.

According to Simarmata (2007), the activity of sulfur-reducing bacteria contributed to the increased concentration of sulfur in the waters. The abundance of sulfur bacteria measured at the beginning and conclusion of the research on the sediment in tanks ranged between $4.4 \times 10^{2}-1.1 \times 10^{4}$ (Table 4). The abundance of sulfur bacteria might be facilitated by the use of sediment without being aerated at the first hand. Hence, there was available sufficient substrate on which the Sulfur Reducing Bacteria (SRB) population grew in abundance. The SRB bacteria were obligate anaerobic bacteria that use sulfate as electron terminal acceptor (Moriarty \& Paullin, 1987). Furthermore, Simarmata (2007) reported that if the depletion rate of oxygen was high, the condition of the waters become even more reductive and finally reached an anaerobic condition which served as a precondition stage for SRB to grow. However, in general, there appeared no significant relationship between the abundance of SRB and concentration of $\mathrm{H}_{2} \mathrm{~S}$, because SRB used sulfur in the form of sulfate and produced $\mathrm{H}_{2} \mathrm{~S}$ via dissimilatory of sulfate reduction. Therefore the relevance of SRB abundance was not autonomous to the presence of sulfate in the waters (Moriaty \& Paullin, 1987; Simarmata, 2007).

Phenol concentration during the research as indicated in Table 3, at station 1, station 2 and station 3 $(0,20,40$ and 60 days) showed similar results with the range of values of less than $0.05 \mathrm{mg} / \mathrm{L}$. These values were argued to be influenced by the redox potential. According to Haeruddin (2006), phenol value is low as the potential redox sediment rises.

The overall value of COD indicated that COD was relatively high particularly on day 20 at station 2 due to the higher concentration of manure from floating fish cages and the amount of oxygen needed in the decomposition process of such material using calcium dichromate (Table 3). The use of calcium dichromate accelerated the decomposition process compared to the natural process due to the more stable

Table 4. The results of bacterial count in the medium during the research

\begin{tabular}{lcc}
\hline \multicolumn{1}{c}{ Sample } & \multicolumn{1}{c}{ Type } & Amount \\
\hline Beginning & SRB (Sulfur Reducing Bacteria) & $4.4 \times 10^{2}$ \\
Conclusion & SRB (Sulfur Reducing Bacteria) & $1.1 \times 10^{4}$ \\
\hline
\end{tabular}


breakdowns of organic material by a microorganism which will indicate higher COD value rather than BOD (Prihadi, 2005).

The dynamic of $\mathrm{pH}$ is shown in Table 2. The values indicated a relatively similar fluctuation of alkalinity throughout 60 days of the research period. This was caused by microorganism releasing $\mathrm{CO}_{2}$ which decreased the oxygen and $\mathrm{pH}$ level in the sediment as a direct result of the decomposition process of organic materials. This is supported by Boyd (1992) where he suggested that soil $\mathrm{pH}$ had a direct influence on the activity of ground microorganism in conducting organic breakdown. Generally, soil microorganisms perform best at $\mathrm{pH}$ between $7.5-8.5$. If the $\mathrm{pH}$ was low, that activity of soil microorganism diminished, causing the accumulation of organic material at the bottom of the pond (Suwoyo, 2009).

Sediment temperature in station 1 and station 2 ranged between $26.3-27.9^{\circ} \mathrm{C}$, with the average value of $27.9^{\circ} \mathrm{C}$, and the approximate temperature of station 3 varied between $26.3-28.0^{\circ} \mathrm{C}$ with the average of $27.9^{\circ} \mathrm{C}$. Water temperature in station 1 ranged between $26.3-28.3^{\circ} \mathrm{C}$ with the average value $28.2^{\circ} \mathrm{C}$. Station 2 and station 3 showed a similar average temperature of $28.1^{\circ} \mathrm{C}$ (Table 2).

The temperature increased starting from day 20 (Table 2). It was suspected that decomposition of organic material by microorganism played role in this temperature change. According to Beveridge (1996); Zonneveld et al. (1991) Effendi (2007), water temperature is the most important aspect which affects the physiology process of fish and other microorganisms. The rising of temperature boosts their metabolism and stimulates more activities, decomposition, feeding, energy needed for maintenance, enzyme activities, small molecules diffusion, membrane function and accelerate protein synthesis (Houlihan et al., 1993).

The total estimation of phosphate was relatively high on day 20. This was due to the low availability of oxygen causing water to become anoxic. As a result, the phosphor in the sediment was released into the water column raising its concentration. Phosphor dynamic is also influenced by temperature and $\mathrm{pH}$. If a slight change of temperature and $\mathrm{pH}$ occurred, the settled phosphor at the bottom of the pond diffused in the water (Effendi, 2007).

High variations of measured phosphate values might be attributed to a higher concentration of phosphate in the lower portion of the water body as a direct result of orthophosphate accumulation which settles down from epilimnion to the bottom of the water (Table 3) (Hutagalung \& Rozak, 1997).

Alkalinity measurement showed a relatively high value. This was due to high $\mathrm{pH}$ level. As alkalinity also closely related to $\mathrm{CO}_{2}$ level in a water body, its high value may also be contributed by a high concentration of $\mathrm{CO}_{2}$ (Table 3). According to Boyd (1999) alkalinity level between $35-43.5 \mathrm{mg} / \mathrm{L} \mathrm{CaCO}_{3}$ is considered normal as the natural value of alkalinity is at $40 \mathrm{mg} / \mathrm{L}$. the natural value of alkalinity is never higher than $500 \mathrm{mg} / \mathrm{L} \mathrm{CaCO}_{3}$.

On day 0 for the stations 1,2 , and 3 , the hardness value was low due to the minimum activity of soil bacteria where instead of releasing $\mathrm{CO}_{2}$, it created stability with carbonate acid (Table 3). In an acidic condition, carbonate compounds in the soil began to dissolve. According to Effendi (2006), a water body with hardness less than $120 / \mathrm{LaCO}_{3}$ and more than $500 \mathrm{mg} / \mathrm{L} \mathrm{CaCO}_{3}$ was considered unsuitable for domestic use, agriculture and industry.

The dynamic of calcium level starting from day 20 has shown an increase in values (Table 3). This increase was presumably caused by the forming of calcium carbonate compounds which then accumulated into sediment at the bottom. However, calcium hardness was temporary (Boyd, 1988).

\section{CONCLUSION}

LCA as a quantitative model coupled with Storet Analysis can be used to determine or evaluate the condition of water quality. Measured DO, sulfide phenol, BOD, COD, and total phosphate values were all outside of standard acceptable value. The high amount of organic substrate and bacteria combined with limited water circulation had diminished oxygen concentration in the substrate and reduced the environment substrate quality. The physiochemical characteristics of the sediment distribution showed that in Station 3 (outlet) had high value of nitrite and orthophosphate as well as C-Organic. This research, in which LCA and Storet Analysis were used, concluded that water quality on the surface of Cirata reservoir could be categorized as highly polluted based on IKA_STORET classification.

\section{ACKNOWLEDGEMENT}

We thank the Research and Development Center for Aquaculture, Indonesia for funding this study. Special thanks to Jack Slembrough and Joel Aubin for their contribution in LCA and supporting references for this paper. 


\section{REFERENCES}

APHA (American Public Health Association). (1987). Standard Methods for Examination of Water and Wastewater $17^{\text {th }}$ edition. APHA, AWWA (American Water Work Association) and WPCF (Water Pollution Control Federation). Washington D.C., $3464 \mathrm{p}$.

Basselieve, E.V. \& Schwartz, N. (1976). The treatment of industrial waste. Kogakusha: Mc Graw Hall Inc.

Bengen, D.G. (2000). Introducing and Managing for Mangrove Ecosystem. Center for Coastal and Marine Analysis.Bogor Agricultural University, $58 \mathrm{p}$.

Beveridge, M.C.M. (1996). Cage Aqua-culture (Eds. $2^{\text {nd }}$ ). Fishing News Books LTD. Farnham, Surrey, England, $352 \mathrm{p}$.

Boyd, C.E. (1988). Water quality in ponds for aquaculture. Alabama Agricultural Experiment Station, Auburn University. Birmingham Publishing Co. Alabama.

Boyd, C.E. (1992). Shrimp Ponds Bottom Soil and Sediment Management. Alabama Agricultural Experiment Station, Auburn University. Birmingham Publishing Co. Alabama.

Boyd, C.E. (1999). Management of Shrimp Ponds to Reduce the Eutrophication Potential of Effluents. The Advocate, December 1999, 12-13 pp.

Canter, L.W. (1977). Environmental Impact Assessment. The McGraw-Hill Companies, Oklahoma, 331 p.

Clark, W.A.V. \& Hosking, P.L. (1986). Statistical Methods for Geographers. John Wiley \& Sons, Inc., $513 \mathrm{p}$.

Departemen Kelautan dan Perikanan. (2007). Standard operational procedure, integrated fisheries management of reservoirs in Indonesia. Ministry of Marine and Fisheries collaboration with Australian Centre International Agricultural Research, $55 \mathrm{p}$.

Effendi, H. (2007). Water quality study: For resource management and aquatic environment. Kanasius Publisher. Yogyakarta, 258 pp. (in Indonesian).

Effendi, I., Bugri, H.J., \& Widanari. (2006). The effect of stocking on survival and growth density of giant gourami seed Osphronemus gourami Lac. Jurnal Akuakultur Indonesia, 5(2), 127-135.

Emiryati. (2004). Characteristic of Physical and Chemistry Sediment related to M acrobenthos-comunity on Kendari Bay. [Tesis]. Bogor: Graduate School, Bogor Agricultural University.

Haeruddin. (2006). Integrated Analysis of Sediment for Evaluating Status on wakak-Plambon Coastal Area in Kendal, Central Java. [Disertation]. Bogor: Graduate School, Bogor Agricultural University.

Hochheimer, J.N. (2000). Water Chemistry in Recycle Systems. Ohio State University.
Houlihan, D.F., Mathers, E., \& Foster, A. (1993). Biochemical correlates of growth rate in fish. Pages 45-71. in J.C. Rankin and F.B. Jensen, editors. Fishecophysiology, Chapman and Hall. LondonMadras.

Hutagalung, H.P. \& Rozak, A. (1997). M etode analisis air laut sedimendan biota. Buku 2. LIPI, Jakarta, $182 \mathrm{pp}$.

Jeffries, M. \& Mills, D. (1996). Freshwater Ecology, Principles and Applications. John Wiley and Sons, Chichester, UK, 285 pp.

Kementerian Negara Lingkungan Hidup. (2003). Ministery Decree No. 115/2003: Criteria of Current Water Quality Status Using Storet Methode: Secretary Ministry of Environment.

Kementerian Negara Lingkungan Hidup. (2001). Document Decree No. 82 Water Quality and Waste Management. Jakarta: SecretaryM inistery of Environment.

Metcalf \& Eddy. (1991). Wastewater Engineering: Treatment, Disposal, and Dense. (3 ${ }^{\text {rd }}$ Edition). McGrawHill, Inc. New York, $1334 \mathrm{p}$.

Moriarty, D.J.W. \& Pullin, R.S.V. (1987). Detritus and Microbial Ecology in Aquaculture International Center For Living Aquatic Resources Management. Manila.

Prihadi, T.H., Erlania, \& Iswari, R.A. (2008). Study on global environmental impact of floating net cage culture through application of Life Cycle Assesment (LCA). J. Ris. Akuakultur, 3(2), 263-273.

Prihadi, T.H. (2005). Sustainable Aquaculture in Reservoirs (cased Study in Cirata Reservoir, West Java). [Dissertation]. Bogor: Graduate School, Bogor Agricultural University.

Simarmata, A.H. (2007). Interrelated study between oxygen stock stability with organic material input load in Juanda Reservoir Jatiluhur, West Java. [Dissertation]. Bogor: Graduate School. Bogor Agricultural University.

Suwoyo, H.S. (2009). Oxygen level Consumption of Sediment on Pond Bottom for IntensiveVanamae Shrimp culture. [Thesis].Graduate School, Bogor Agricultural University.

Tebbut, T.H.Y. (1992). Principles of Water Quality Control. Fourth Edition. Pergamon Press, Oxford, $251 \mathrm{p}$.

Widigdo, B. \& Soewardi, K. (1999). Standard Operational Procedure. Monodon Shrimpin TIR Project Karawang. Collaboration PPTIR (Proyek Pandu Tambak Inti Rakyat) and FPIK Bogor Agricultural University, 16 pp.

Zonneveld, N., Huisman, E.A., \& Boon, J.H. (1991). Fish Culture Conseps. PT. Gramedia Pustaka Utama. Jakarta, $318 \mathrm{p}$. 